\title{
Is tobacco a risk factor for chronic pancreatitis and alcoholic cirrhosis?
}

\author{
M Bourliere, M Barthet, P Berthezene, J P Durbec, H Sarles
}

\begin{abstract}
In a case control study alcohol intake and tobacco use were assessed between 1975 and 1987 in 103 male patients suffering from alcoholic cirrhosis of the liver, in 145 patients with chronic pancreatitis, and in 264 control subjects. The patients with chronic pancreatitis were significantly younger than the patients with cirrhosis (mean (SD) age 41.92 (2.4) $v 60.9(11.6)$ years). Among the patients with chronic pancreatitis, $94 \%$ were both smokers and drinkers compared with $83 \%$ of patients with cirrhosis of the liver. The relative risks for each disease were calculated by conditional multiple logistic regression. Whereas daily intake of alcohol was a major risk factor for both cirrhosis of the liver and chronic pancreatitis, smoking was significantly related only to the risk of having chronic pancreatitis. Moreover, the mean age at onset of pancreatitis was lower among smokers.
\end{abstract}

In 1878 Friedreich ${ }^{1}$ was the first to suspect the role of heavy alcohol consumption in the aetiology of pancreatitis. His observation has since been supported by many clinical studies. ${ }^{2-4}$ Later, Durbec and Sarles showed that the logarithm of the risk of developing alcoholic chronic pancreatitis was linearly correlated with the mean daily alcohol consumption. ${ }^{+}$More recently, Yen $e t a l^{5}$ pointed out that chronic pancreatitis was strongly associated not only with alcohol consumption but also with cigarette smoking, the apparent effect of tobacco being dissociated from the effect of alcohol. Lowenfels et $a l^{6}$ showed that in the male American Indian population smoking was more frequent among chronic pancreatitis patients than among patients with alcoholic liver cirrhosis. Smoking and drinking, however, generally coexist as social habits. ${ }^{7}$ The aim of the present casecontrol study was to investigate the relative contributions of alcohol and tobacco as risk factors for chronic pancreatitis and cirrhosis of the liver.

Unité de recherches de Physiologie et de Pathologie Digestives, U 315 INSERM, 46 boulevard de la Gaye, 13258 Marseille Cédex 9 , France

M Bourliere

M Bourliere
M Barthet

P Berthezene

P Durbec

H Sarles

Correspondence to:

DrM Barthet, INSERM U

315,46 boulevard de la Gaye, 13009 Marseille, France.

Accepted for publication 25 February 1991 cases of chronic pancreatitis diagnosed between 1975 and 1987. The diagnosis was based on (i) pancreatic stones (calcifications) visible on $x$ ray films of the abdomen (91 of 147 patients), (ii) on typical pancreatitis pain associated with modifications of pancreatic ducts at endoscopic retrograde cholangiopancreatography (94 of 147 patients), ${ }^{9}$ and on exocrine pancreatic insufficiency estimated from duodenal juice collected after injection of secretin and cholecystokinin (81 of 147 patients).

Between 1980 and 1987 the same questionnaire was used for 173 patients presenting with alcoholic cirrhosis of the liver. The diagnosis of alcoholic cirrhosis was based on clinical, biological, histological (liver biopsy), and nutritional data. Nineteen patients with cirrhosis were excluded because of missing data on alcohol consumptions and tobacco use. Seven patients with both cirrhosis and chronic pancreatitis were also excluded. Thus 103 men with alcoholic cirrhosis were studied. Between 1985 and 1988 a control group was selected from interviews carried out during systematic medical examinations for the French social security system. Cases and control subjects were investigated by specially trained dietitians on alcohol, smoking, and dietary habits. Particular attention was given to the duration and intensity of smoking and to the age at starting and stopping smoking. Questions were asked about the amount, frequency, and duration of alcohol consumption at and before the onset of the disease. We only took into account the patients who provided full information on their drinking and smoking habits (145 chronic pancreatitis, 147 cirrhosis of the liver, 264 control subjects). Daily alcohol consumption was expressed as $\mathrm{ml} /$ day, tobacco use as average grams of tobacco per day and in $\mathrm{kg}$ before the onset of the disease.

Statistical analyses were performed with Student's $t$ test, the Mann-Whitney U test, the Kruskall-Wallis one way analysis of variance on ranks, and Spearman's rank coefficients. We used conditional multiple logistic regression to estimate the relative risks of chronic pancreatitis or cirrhosis of the liver for each variable (daily consumption of alcohol or of tobacco use, lifetime use of tobacco, body mass index).${ }^{10}$ Cases of chronic pancreatitis or of cirrhosis were matched to one or several control subjects in 10 year age groups to compensate in this model for the age difference between patients with chronic pancreatitis and cirrhosis of the liver and control subjects. ${ }^{10}$ So the logarithm of the relative risk was expressed as a linear combination of each variable studied and of parameters estimated by method of maximum conditional likelihood. The variables were examined for separate associations with chronic pancreatitis or cirrhosis, for confounding factors, and for interaction. Statistical significance was tested for by comparing deviance differences with log likelihood ratio tests." Computer software (Computer Fortran 5 program $)^{12}$ was a generous gift of $\mathrm{J} \mathrm{H}$ Lubin. We showed that studying our patients and control subjects at different time periods would not 
TABLE I Age, daily intake of alcohol, and cigarette use at different periods (mean (SD)) among patients with chronic pancreatitis $(C P)$, control subjects $(C)$, and patients with liver cirrhosis $(L C)$

\begin{tabular}{|c|c|c|c|c|}
\hline & $1975-80$ & $1981-5$ & $1986-7$ & $p$ \\
\hline \multicolumn{5}{|c|}{ No of patients: } \\
\hline $\mathrm{CP}$ & 57 & 65 & 10 & \\
\hline $\begin{array}{l}\mathrm{C} \\
\mathrm{LC}\end{array}$ & 0 & 167 & 33 & \\
\hline \multicolumn{5}{|c|}{$\begin{array}{l}\text { LC } \\
\text { Age (years): }\end{array}$} \\
\hline${ }_{\mathrm{C}}^{\mathrm{CP}}$ & $41 \cdot 2(8 \cdot 6)$ & $\begin{array}{l}42 \cdot 9(11 \cdot 7) \\
57 \cdot 9(13 \cdot 4)\end{array}$ & $39 \cdot 1(10 \cdot 4)$ & $=0.44$ \\
\hline LC & & $61.9(12)$ & $58 \cdot 9(10)$ & $=0.23$ \\
\hline $\begin{array}{l}\text { Alcoho } \\
\text { CP } \\
\text { C }\end{array}$ & $\begin{array}{l}\text { kee (m//day): } \\
\quad 191.0(155 \cdot 5)\end{array}$ & $\begin{array}{c}172 \cdot 9(107 \cdot 2) \\
38 \cdot 6(48 \cdot 2)\end{array}$ & $188 \cdot 0(100 \cdot 2)$ & $=0.72$ \\
\hline LC & 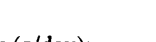 & $171.5(97.6)$ & $170 \cdot 4(114)$ & $=0.96$ \\
\hline $\begin{array}{c}\text { Tobacc } \\
\text { CP }\end{array}$ & $\begin{array}{l}\text { (g/day): } \\
272 \cdot(15 \cdot 2)\end{array}$ & $\begin{array}{l}27 \cdot 1(16 \cdot 2) \\
15 \cdot 7(18)\end{array}$ & $24 \cdot 0(9 \cdot 9)$ & $=0.82$ \\
\hline LC & & $25 \cdot 2(21)$ & $25 \cdot 4(20 \cdot 7)$ & $=0.95$ \\
\hline $\begin{array}{l}\text { Body m } \\
\text { CP }\end{array}$ & $\begin{array}{c}\text { index }\left(\mathrm{kg}^{2} / \mathrm{cm}\right) \\
21 \cdot 2(2 \cdot 8)\end{array}$ & $20 \cdot 9(2 \cdot 9)$ & $21 \cdot 0(2 \cdot 8)$ & $=0.90$ \\
\hline $\begin{array}{l}\mathrm{C} \\
\mathrm{LC}\end{array}$ & & $\begin{array}{l}24 \cdot 9(3 \cdot 9) \\
24 \cdot 1(4 \cdot 6)\end{array}$ & $25 \cdot 2(4 \cdot 9)$ & $=0.24$ \\
\hline
\end{tabular}

TABLE II Distribution of patients with chronic pancreatitis $(C P)$, control subjects $(C)$, and of patients with cirrhosis (LC) by sex, cigarette use, and alcohol consumption (all values mean $(S D)$ are given for men only)

\begin{tabular}{|c|c|c|c|}
\hline & $C P$ & $C$ & $L C$ \\
\hline \multicolumn{4}{|l|}{ Number: } \\
\hline Total & 145 & 264 & 147 \\
\hline Men & 132 & 167 & 103 \\
\hline Women & & 97 & 44 \\
\hline $\begin{array}{l}\text { Age (years): } \\
\text { CP } v \text { C }\end{array}$ & $\begin{array}{l}41.9(10.4) \\
\mathrm{p}<0.001\end{array}$ & $57 \cdot 9(13 \cdot 4)$ & $60 \cdot 9(11 \cdot 6)$ \\
\hline $\mathrm{CP} v \mathrm{LC}$ & & & $\mathrm{p}<0.001$ \\
\hline $\begin{array}{l}\text { Alcohol intake (ml/day): } \\
\text { CP } v \text { C }\end{array}$ & $\begin{array}{c}182 \cdot 6(129 \cdot 2) \\
\mathrm{p}<0.001\end{array}$ & $38 \cdot 6(48 \cdot 2)$ & $171 \cdot 2(102 \cdot 6)$ \\
\hline $\begin{array}{l}\text { CP } v \text { LC } \\
\text { Tobacco use (g/dav): }\end{array}$ & $26 \cdot 9(15 \cdot 3)$ & $15 \cdot 7(18)$ & $\begin{array}{l}p=0 \cdot 46 \\
25 \cdot 2(20 \cdot 8)\end{array}$ \\
\hline $\begin{array}{l}\text { CP } v \text { C } \\
\text { CP } v \text { LC }\end{array}$ & $\mathrm{p}<0.001$ & & $p=0.48$ \\
\hline $\begin{array}{l}\text { \% Drinkers: } \\
\text { CP v C } \\
\text { CP v LC }\end{array}$ & $\stackrel{100}{\mathrm{p}<0.01}$ & 67 & 100 \\
\hline \multirow{3}{*}{$\begin{array}{l}\text { \% Smokers: } \\
\text { CP v C } \\
\text { CP } v \text { LC } \\
\text { Body mass index }\left(\mathrm{kg}^{2} / \mathrm{cm}\right): \\
\text { CP } v \text { C } \\
\text { CP } v \text { LC }\end{array}$} & $\begin{array}{l}94 \\
\mathrm{p}<0.01\end{array}$ & 61 & \multirow{3}{*}{$\begin{array}{l}83.5 \\
p<0.01 \\
24 \cdot 4(4 \cdot 7) \\
p<0.001\end{array}$} \\
\hline & $\begin{array}{l}21 \cdot 1(2.9) \\
p<0.001\end{array}$ & $24 \cdot 9(3 \cdot 9)$ & \\
\hline & & & \\
\hline
\end{tabular}

TABLE III Comparison between men with chronic pancreatitis $(C P)(n=132)$ and male control subjects $(C)(n=167)$ by age at onset of disease, alcohol consumption, and cigarette use (mean $(S D))$

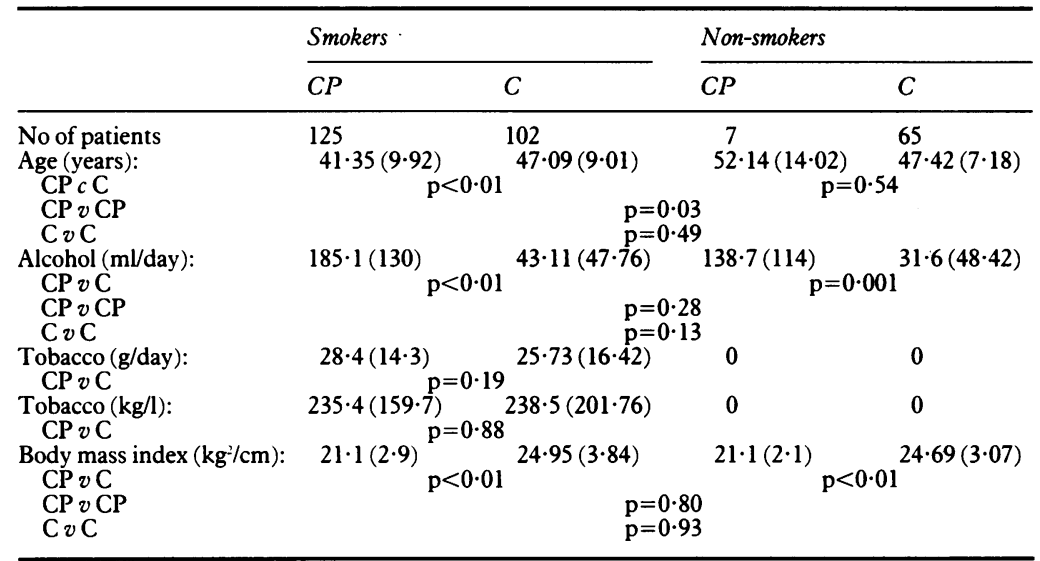

Student's $t$ test between $\mathrm{C}$ and CP in each group; Mann-Whitney $\mathrm{U}$ test between $\mathrm{CP}$ in the two groups.

influence our results (Table I). For descriptive purposes, data have been expressed as mean (SD).

\section{Results}

WOMEN

We did not take women into account in this case- control study because of the small number of women affected by chronic pancreatitis (13 of 145). Such a small number does not allow us to draw any definite conclusion concerning women. So daily intake of alcohol and tobacco use were only studied for 132 male patients with chronic pancreatitis, 103 male patients with cirrhosis of the liver, and 167 male control subjects (Table II).

\section{CONTROL SUBJECTS}

Among the 264 control subjects, 167 were men; 112 men $(67 \%)$ were drinkers and 102 men $(61 \%)$ were smokers (Table II); $76(67 \cdot 8 \%)$ were both drinkers and smokers. Smokers were not found to be different from non-smokers for age, daily intake of alcohol, and body mass index (Table III).

After classifying subjects by smoking habits (none, $<10 \mathrm{~g} /$ day, $10-20 \mathrm{~g} /$ day, $>20 \mathrm{~g} /$ day) no relation between tobacco use and alcohol consumption was found among the 167 male control subjects (Table IV).

After classifying subjects by daily intake of alcohol, however, the heavier drinkers were found to be the heavier smokers (Table V). The percentage of heavy male drinkers (more than $100 \mathrm{ml} /$ day) was higher among chronic pancreatitis patients $(77 \cdot 3 \%$ of total) than among control subjects $(10 \cdot 2 \%$ of total). So in controls the heavier drinkers were also the heavier smokers, but the opposite was not true.

No correlations were found between age and tobacco use or between age and alcohol consumption using non-parametric correlations (Table VI).

\section{CHRONIC PANCREATITIS}

Among the 145 patients with chronic pancreatitis 132 were men $(91 \%)$ and 13 were women (9\%); the mean (SD) age of the men was 41.92 $(2 \cdot 4)$ years (Table II). Alcohol was found to be the most common aetiological factor: 132 patients with chronic pancreatitis were drinkers $(100 \%) ; 125(94 \cdot 4 \%)$ used tobacco.

Among the 132 men, 125 were both drinkers and smokers $(94 \cdot 7 \%)$ and seven only drinkers. The mean age at the time of diagnosis was significantly lower in smokers $(41.35(9.9)$ years) than in non-smokers $(52 \cdot 14(14 \cdot 02)$ years) (Table III). Body mass index and daily alcohol consumption were the same among smokers and non-smokers (Table III).

After classifying patients by smoking history (none, $<10 \mathrm{~g} /$ day, $10-20 \mathrm{~g} /$ day, $>20 \mathrm{~g} /$ day) a significant relation between tobacco use and daily intake of alcohol $(p=0.036)$ was observed (Table IV). Moreover, there was a reciprocal relation between alcohol consumption and daily tobacco use when the sample was stratified according to alcohol consumption (Table V). Thus, the heavier drinkers were also the heavier smokers, and vice versa.

Table VI shows that there is no linear correlation between the age at onset of disease and tobacco use, whereas there is a significant slight negative correlation between age at onset of disease and daily intake of alcohol. 
TABLE IV Daily intake of alcohol in male control subjects $(C)(n=167)$ and in male patients with chronic pancreatitis $(C P)(n=132)$ and cirrhosis $(L C)(n=103)$ after stratifying by smoking history (mean (SD))

\begin{tabular}{|c|c|c|c|c|c|}
\hline & \multicolumn{4}{|c|}{ Tobacco (g/day) } & \multirow[b]{2}{*}{$p$} \\
\hline & 0 & $0-10$ & $10-20$ & $>20$ & \\
\hline $\begin{array}{l}\text { \% of patients: } \\
\text { CP } \\
\text { C } \\
\text { LC }\end{array}$ & $\begin{array}{r}5 \cdot 3 \\
39 \cdot 0 \\
16 \cdot 5\end{array}$ & $\begin{array}{r}6 \cdot 8 \\
10 \cdot 0 \\
9 \cdot 7\end{array}$ & $\begin{array}{l}44 \cdot 7 \\
26 \cdot 0 \\
36 \cdot 9\end{array}$ & $\begin{array}{l}43 \cdot 2 \\
24 \cdot 0 \\
36 \cdot 9\end{array}$ & \\
\hline $\begin{array}{l}\text { Alcohol (ml/day): } \\
\text { CP } \\
\text { C } \\
\text { LC }\end{array}$ & $\begin{array}{c}138 \cdot 7(43 \cdot 1) \\
31 \cdot 6(6 \cdot 0) \\
203 \cdot 6(75 \cdot 1)\end{array}$ & $\begin{array}{r}97 \cdot 3(17 \cdot 4) \\
42 \cdot 4(10 \cdot 0) \\
124 \cdot 1(54 \cdot 6)\end{array}$ & $\begin{array}{c}191 \cdot 8(19 \cdot 1) \\
45 \cdot 6(6 \cdot 3) \\
164 \cdot 3(105 \cdot 1)\end{array}$ & $\begin{array}{c}192 \cdot 0(15 \cdot 4) \\
40 \cdot 7(8 \cdot 8) \\
176 \cdot 1(116 \cdot 9)\end{array}$ & $\begin{array}{l}=0.03 \\
=0.48 \\
=0.03\end{array}$ \\
\hline
\end{tabular}

Standard analysis of variance.

TABLE V Daily tobacco use in male control subjects $(C)(n=167)$ and in male patients with chronic pancreatitis $(C P)(n=132)$ and cirrhosis $(L C)(n=103)$ after stratifying by alcohol consumption (mean (SD))

\begin{tabular}{|c|c|c|c|c|c|}
\hline & \multicolumn{4}{|c|}{ Alcohol (ml/day) } & \multirow[b]{2}{*}{$p$} \\
\hline & 0 & $0-50$ & $50-100$ & $>100$ & \\
\hline \multicolumn{6}{|l|}{$\%$ of patients: } \\
\hline $\mathrm{CP}$ & 0 & $5 \cdot 3$ & $17 \cdot 4$ & $77 \cdot 3$ & \\
\hline $\mathrm{C}$ & 33 & $34 \cdot 7$ & $22 \cdot 1$ & $10 \cdot 1$ & \\
\hline LC & 0 & $5 \cdot 8$ & $23 \cdot 3$ & 70.9 & \\
\hline \multirow{4}{*}{$\begin{array}{l}\text { Tobacco (g/day): } \\
\text { CP } \\
\text { C } \\
\text { LC }\end{array}$} & & & & & \\
\hline & & $13 \cdot 3(4 \cdot 2)$ & $24 \cdot 6(3 \cdot 3)$ & $28 \cdot 3(1 \cdot 5)$ & $<0.01$ \\
\hline & $12 \cdot 8$ & $17 \cdot 3(2 \cdot 1)$ & $11.9(2.4)$ & $27 \cdot 9(5 \cdot 8)$ & $=0.008$ \\
\hline & & $33 \cdot 3(16 \cdot 3)$ & $20 \cdot 8(10 \cdot 4)$ & $26 \cdot 0(23 \cdot 4)$ & $=0.31$ \\
\hline
\end{tabular}

Standard analysis of variance. ables - they still both apperared as risk factors for chronic pancreatitis (Table VII): in this case alcohol habit $\left(\chi^{2}=28 \cdot 84,1\right.$ degree of freedom, $\left.\mathrm{df}\right)$ was more important as a risk factor than smoking habit $\left(\chi^{2}=4.41,1 \mathrm{df}\right)$ (Table VII). These variables, however, have a multiplying effect on the relative risk of pancreatitis, since the logarithm of this relative risk is a linear combination of the variables studied.

\section{ALCOHOLIC CIRRHOSIS}

Altogether, 103 men with alcoholic cirrhosis of the liver were studied. The mean (SD) age at onset of disease was $60.9(11.6)$ years. The mean (SD) daily alcohol consumption was $171 \cdot 2$ $(102.6) \mathrm{ml} /$ day and mean (SD) tobacco use was $25 \cdot 2(20 \cdot 8) \mathrm{g} /$ day. The mean (SD) body mass index was 24.4 (4.7) (Table II). Eighty six patients $(83.5 \%)$ were both drinkers and smokers. Their mean tobacco use was $30 \cdot 23$ $(19 \cdot 2) \mathrm{g} /$ day. Seventeen patients were drinkers only. Age at onset of disease, body mass index, and daily alcohol consumption were the same among smokers and non-smokers (Table VIII).

After classifying patients by smoking history (none, $<10 \mathrm{~g} /$ day, $10-20 \mathrm{~g} /$ day, $>20 \mathrm{~g} /$ day), a significant relation between tobacco use and daily intake of alcohol $(p=0.037)$ was found (Table IV). No relation was found, however, between alcohol consumption and daily tobacco use when the sample was stratified by alcohol consumption (Table V). Thus in cirrhosis of the liver the heavier smokers were the heavier drinkers, but not the opposite.

Only daily alcohol intake seemed to be a risk factor for alcoholic cirrhosis (Table IX). When daily alcohol intake and tobacco use were studied simultaneously - that is, without interaction between these variables - daily tobacco use no longer appeared as a risk factor for alcoholic cirrhosis.

( $\mathrm{g} /$ day or $\mathrm{kg}$ ) in chronic pancreatiti

\begin{tabular}{|c|c|c|c|c|}
\hline & \multicolumn{4}{|l|}{ Variables } \\
\hline & $\beta$ & $S E$ & $Z$ & $R R$ \\
\hline Alcohol (ml/day) & $0.3010^{-2 \star}$ & $0.4910^{-3}$ & $\begin{array}{l}6 \cdot 125 \\
\mathrm{p}<0.001\end{array}$ & $1.003^{\star}$ \\
\hline Tobacco (g/day) & $0 \cdot 1510^{-1 \star}$ & $0.4410^{-2}$ & $\begin{array}{l}3.38 \\
\mathrm{p}<0.001\end{array}$ & $1.015^{\star}$ \\
\hline Tobacco (kg/l) & $0.6710^{-2 \star}$ & $0.2310^{-2}$ & $\begin{array}{l}2.92 \\
p<0.003\end{array}$ & $1 \cdot 007^{\star}$ \\
\hline Alcohol (g/day) & $0.2710^{-2 \star}$ & $0.5110^{-3}$ & 5.37 & $1.003^{\star}$ \\
\hline Tobacco (g/day) & $0.9910^{-2 \star}$ & $0.4710^{-2}$ & $\begin{array}{l}\mathrm{p}<0.001 \\
2 \cdot 107 \\
\mathrm{p}<0.035\end{array}$ & $1.010^{\star}$ \\
\hline Alcohol (g/day) & $0.2710^{-2 \star}$ & $0.5110^{-3}$ & 5.35 & $1.003^{\star}$ \\
\hline Tobacco $(\mathrm{kg} / \mathrm{l})$ & $0 \cdot 1110^{-5 \star}$ & $0.4610^{-6}$ & $\begin{array}{l}\mathrm{p}<0<.001 \\
2.46 \\
\mathrm{p}<0.0014\end{array}$ & $1.0^{\star}$ \\
\hline Alcohol (g/day) & $0.2710^{-2 \star}$ & $0.5110^{-2}$ & $5 \cdot 37$ & $1.003^{\star}$ \\
\hline Tobacco (g/day) & $0.9010^{-2 \star}$ & $0.4410^{-3}$ & & \\
\hline Tobacco $(1$ & $0.5410^{-2 \star}$ & $0.2610^{-2}$ & $\begin{array}{l}\mathrm{p}<0.057 \\
2.03 \\
\mathrm{p}<0.042\end{array}$ & $1.005^{\star}$ \\
\hline
\end{tabular}

${ }^{\star} \mathrm{p}<0.05, \log \mathrm{RR}=\Sigma_{\mathrm{i}=1, \mathrm{n}} \beta_{\mathrm{i}}\left(\mathrm{X}_{\mathrm{i}}^{\prime}-\mathrm{X}_{\mathrm{i}}\right)$

$\beta$ : estimated parameter; $S E$ : standard error; $Z$ : ratio of $\beta$ to its standard error.

Daily intake of alcohol, daily tobacco use, and lifetime tobacco use separately seemed to be risk factors for pancreatitis (Table VII). When the effects of daily alcohol intake and daily tobacco use or lifetime use were studied simultaneously that is, without interaction between these vari-
TABLE VIII Comparison by age, daily alcohol intake, and alcoholic cirrhosis

\begin{tabular}{|c|c|c|c|}
\hline & Smokers & $p$ & Non-smokers \\
\hline No of patients & 86 & & 17 \\
\hline $\begin{array}{l}\text { Age (years) at onse } \\
\text { disease }\end{array}$ & $61 \cdot 3(11 \cdot 5)$ & $\mathrm{p}=0.52$ & $59 \cdot 3(12 \cdot 3)$ \\
\hline $\begin{array}{c}\text { Alcohol (ml/day) } \\
(\text { mean }(\mathrm{SD}))\end{array}$ & $164 \cdot 8$ & $=0$ & 203. \\
\hline $\begin{array}{l}\text { Body mass index }\left(\mathrm{kg}^{2} / \mathrm{cm}\right) \\
(\text { mean }(\mathrm{SD}))\end{array}$ & $24 \cdot 3(4 \cdot 5)$ & $\mathrm{p}=0.55$ & $25 \cdot 0(5 \cdot 8)$ \\
\hline
\end{tabular}

TABLE IX Relative risk of alcohol (g/day) and tobacco (g/day) in alcoholic cirrhosis

\begin{tabular}{|c|c|c|c|c|}
\hline & \multicolumn{4}{|l|}{ Variables } \\
\hline & $\beta$ & $S E$ & $Z$ & $R R$ \\
\hline Alcohol (ml/day) & $0.5110^{-2 \star}$ & $0.6210^{-3}$ & $\begin{array}{l}8.251 \\
p<0.001\end{array}$ & $1 \cdot 005^{\star}$ \\
\hline Tobacco (g/day) & $0 \cdot 1010^{-1 \star}$ & $0.4310^{-2}$ & $\begin{array}{l}2.31 \\
p<0.021\end{array}$ & $1 \cdot 010^{\star}$ \\
\hline Alcohol (ml/day) & $0.5110^{-2 \star}$ & $0.6710^{-3}$ & $\begin{array}{l}7.62 \\
p<0.001\end{array}$ & $1.005^{\star}$ \\
\hline Tobacco (g/day) & $0.1710^{-2} \dagger$ & $0.4710^{-2}$ & $\begin{array}{l}\mathrm{p}<0.36 \\
\mathrm{p}<0.71\end{array}$ & $1.002 \dagger$ \\
\hline
\end{tabular}

${ }^{\star} \mathrm{p}<0.05$; not significant

$\beta$ : estimated parameter; SE: standard error; Z: ratio of $\beta$ to its standard error. body mass index, between smokers and non-smokers with 


\section{Discussion}

Smoking and drinking are social habits that generally coexist. ${ }^{7}$ In the United States Yen $e t a^{5}$ and Lowenfels et $a l^{6}$ first suggested that smoking is a risk factor for alcoholic pancreatitis in male patients. However, smoking and drinking habits differ world wide. For example, $63 \%$ of male control subjects in the United States ${ }^{5}$ and $33 \%$ in France ${ }^{7}$ were non-smokers. Therefore, the aim of this case-control study was to investigate the relative contribution of tobacco as a risk factor among men in France in two alcohol related diseases - chronic pancreatitis and cirrhosis of the liver. We may first observe that the epidemiological characteristics of our three samples (patients with chronic pancreatitis and cirrhosis of the liver and control subjects) are similar to those reported in previous studies. In our chronic pancreatitis group the sex ratio $(91 \%$ male), age at onset of the disease ( 41.9 years), and daily alcohol consumption are the same as in other French studies. ${ }^{1{ }^{1+}}$ The same is true for sex ratio (70\% of males) and daily consumption of alcohol in cirrhosis. ${ }^{15} 16$ The age at diagnosis of cirrhosis of the liver is the same in our sample as in previous French and Swiss studies, ${ }^{15}{ }^{17}$ but is higher than in previous German ${ }^{18}$ or American ${ }^{619}$ studies. The proportion of smokers and drinkers, and the mean daily consumption of alcohol and tobacco use in our control sample is the same as in the previous large epidemiological studies, ${ }^{72}{ }^{21}$ but differs from that reported in the American study of Yen $e t a l .^{5}$ This emphasises the differences in smoking and drinking habits in various countries.

It is worth noting that the relation between alcohol and tobacco is not the same in chronic pancreatitis, cirrhosis, and control subjects. In chronic pancreatitis heavy drinkers develop pancreatitis sooner and the average daily consumption of alcohol and tobacco use are closely correlated. This is not found in cirrhosis, where only heavy smokers are heavy drinkers, nor in control subjects where heavy drinkers are heavy smokers. This may explain the finding that although average daily use of tobacco and alcohol are the same in cirrhosis and chronic pancreatitis, tobacco appears as risk factor only for chronic pancreatitis. This conclusion agrees with those of Yen $e t$ al and Lowenfels $e t$ al, but all of these epidemiological studies are case-control studies were populations showed different epidemiological characteristics. ${ }^{56}$ In a casecontrol study, rather than an on-going study, bias can be introduced and conclusions must be carefully drawn. However, we try to show in Table I that epidemiological features in chronic pancreatitis and in liver cirrhosis did not change during our study. There is also a potential for bias in the selection of the control subjects. As we saw later, our control subjects do not seem much different from the control subjects in other large epidemiological French or European studies. ${ }^{72021}$

Therefore, further epidemiological studies, especially on-going studies, are mandatory to study the relation between alcohol, tobacco, and nutritional data in these two diseases.

1 Friedreich N. Chronic pancreatitis. In: Von Ziemssen H, ed. Cyclopaedia of the practice of medicine. New York: William Wood, 1878: 599-608.

2 Sarles H, Cros RC. International group for the study of pancreatic diseases. A multicenter inquiry into the etiology of pancreatic diseases. Digestion 1978; 19: 110-25.

3 Voirol M Infante $O$, Brahime-Retuno $O$, Raymond L, Hollenweger V, Loizeau E. Consommation d'alcool, de tabac et de nutriments dans les affections pancreatiques. tabac et de nutriments dans les affections
Schweiz Med Wochenschr 1980; 110: 854-5.

4 Durbec JP, Sarles H. Multicenter survey of the etiology of pancreatic diseases. Digestion 1978; 18: 337-50

5 Yen S, Hsieh CC, MacMahon B. Consumption of alcohol and tobacco and other risk factors for pancreatitis. $\mathrm{Am} \mathcal{J}$ Epidemiol 1982; 116: 407-14.

6 Lowenfels AB, Zwemer FL, Jhangiani S, Pitchumoni CS. Pancreatitis in a native American Indian population. Pancreas 1987; 6: 694-7.

7 Tuyns AJ, Pequignot G, Jensen O, Pomeau Y. La consommation individuelle de boissons alcoolisées et de tabac dans un échantillon de la population en Ille et Vilaine. La Revue de échantillon de la population en
l'Alcoolisme 1975; 21: $105-47$.

8 Cros C, Borillo M, Bernard P, Gardin JC, Gauthier AP, Sarles H. Principes d'un système descriptif des signes médicaux et d'organisation du champ des diagnostics par l'étude de la pathologie digestive sur ordinateur. Pathol Biol (Paris) 1968 16: $671-6$.

9 Sahel J, Lombard C, Sarles H. Etude morphométrique des canaux pancréatiques normaux et pathologiques opacifiés par cathétèrisme endoscopique de la papille. Arch $\mathrm{Fr} \mathrm{Mal}$ App Dig 1976; 65: 431-4.

10 Breslow NE, Day NE. Statistical methods in cancer research. The analysis of case-control studies. Lyon, France: IARC, 1980: analysis of case-control studies.
Vol 1. (IARC Sci Publ No 32.)

11 Schlesselman JJ. Case-control studies. Design, conduct, analysis. New York: Oxford University Press, 1982.

12 Lubin JH. A computer program for the analysis of matched case-control studies. Comput Biomed Res 1981; 14: 138-43.

13 Sarles H, Sarles JC, Camatte R, Muratore R, Gaini M, Guien $\mathrm{C}$, et al. Observations on 205 confirmed cases of acute pancreatitis, recurring pancreatitis and chronic pancreatitis. Gut 1965; 6: 545-59.

14 Sarles $H$. An international survey on nutrition and pancreatitis. Digestion 1973; 9: 389-403.

15 Pequignot G, Tuyns AJ, Berta JL. Ascitic cirrhosis in relation to alcohol consumption. Int f Epidemiol 1978; 7: 113-20.

16 Durbec JP, Bidart JM, Sarles H. Etude des variations du risque de cirrhose du foie en fonction de la consommation risque de cirrhose du foie en fonction de la con
d'alcool. Gastroenterol Clin Biol 1979; 3: 725-34.

17 Raymond L, Infante F, Voirol M, et al. Interaction des facteurs alcool et nutrition dans l'étiologie de la cirrhose hépatique dhez les hommes. Schweiz Med Wochenschr 1985; 115: $998-1000$

18 Lellbach WK. Cirrhosis in the alcoholic and its relation to the volume of alcohol abuse. Ann NYAcad Sci 1975, 252: 85-105.

19 Patek AJ, Toth IG, Saunders MG, Castro GAM, Engel JJ. Alcohol and dietary factors in cirrhosis. Arch Intern Med 1975; 135: 1053-7.

20 Berrino F, Merletti F, Zubiri A, Del Moral A, Raymond L, Esteve J, et al. A comparative study of smoking, drinking and dietary habits in population samples in France, Italy, and dietary habits in population samples in France, Italy,
Spain and Switzerland. II Tobacco smoking. Rev Epidemiol Santé Publique 1988; 36: 166-70.

21 Pequignot G, Crosagni P, Terracini B, Ascunce N, Zubiri A, Raymond L, et al. A comparative study of smoking, dietary habits in population samples in France, Italy, Spain and Switzerland. III Consumption of alcohol. Rev Epidemiol Santé Publique 1988; 36: 177-85. 